\title{
Investigation of Participation and Quality of Online Interaction
}

\author{
Dip Nandi \\ American International University- Bangladesh, Dhaka, 1213, Bangladesh \\ Email: dip.nandi@aiub.edu \\ Margaret Hamilton, James Harland \\ School of Computer Science and Information Technology RMIT University, Melbourne, Victoria - 3001, Australia \\ Email: \{margaret.hamilton, james.harland\}@rmit.edu.au \\ Sharfuddin Mahmood \\ American International University- Bangladesh, Dhaka, 1213, Bangladesh \\ Email:smahmood@aiub.edu
}

\begin{abstract}
Advances in computer mediated communication technologies have sparked and continue to facilitate the proliferation of online courses, degree programs, and educational institutions. Leading the way with these advances has been the use of asynchronous discussion forums. However merely setting up a discussion forum does not always ensure quality participation and interaction. The way the course is managed has an impact on the participation as well. This paper compares the difference in course management over four study periods and discusses the resulting consequences on the participation and achievement of the students. This paper also investigates the quality of interaction as perceived by fully online students. The main benefits of this research are that it provides a guideline regarding what course management factors can make the difference in online participation in fully online courses, and how the quality of interaction can be designed.
\end{abstract}

Index Terms - Online learning system, Participation, Asynchronous discussion forums, online collaboration, Interaction quality, and course management.

\section{INTRODUCTION}

The incessant enhancement of internet enabled online learning has ensured that discussion forums are now a necessity for productive engagement between learners and instructors. A major focus has always been on the better use of technology to support learning, in particular with the introduction of Web 2.0 technologies. There is a need for research into the ways in which effective online participation can be designed in fully online computing courses. Many "best practices" are based on intuition, personal experience and traditional instructional methods rather than on better use of technology and not on empirically based research [1].

The processes of online teaching break into design perspective and method of delivery [2]. Learners have different ways for receiving and processing of information [3] As a result, there is a need for research into the ways in which effective online participation can be designed in fully online computing courses. In this paper we present our research about what factors of the online environment or course management have an impact on student participation and achievement. The data for this extensive research was collected throughout four study periods and we investigate both the quantitative and qualitative aspects of online participation as follows:

- What do students say they want? We design a survey and present the findings of our analysis regarding the criteria that are considered valuable by students while discussing online.

- What do instructors find they want? This paper presents the findings of quantitative data analysis regarding the impact of course management factors on the participation of the fully online students and whether these factors contribute towards their results.

We investigate different alterations made by the instructors in two of these fully online courses over four study periods and identify the consequences those changes had on the participation and achievements of the students. We present the Related Works in Section ii, The Research Methods employed in Section iii, Data Collections and Analysis in Section iv, Discussion in Section $\mathrm{v}$ and finally the Concluding statements in Section vi.

\section{RELATED WORKS}

\section{A. Online Participation}

Advances in communication technologies and the growing application of constructivist pedagogy that is 
learner-centered, rather than teacher-centered, have changed the focus from a traditional independent learner model to one informed by social constructivism and collaborative learning principles. In order to facilitate this collaboration, increasing use of information and communication technologies and online discussions or web-based conferences have become an integral part of new models of online learning and teaching. Through networked communications, geographically dispersed students are able to participate in online discussions and group work with their instructors and peers which can reduce isolation and increase engagement in this world of globalization [4].

Online learning is growing rapidly as it provides students and educational institutions with great flexibility and environments and interactivity have become the focus of ongoing research.

\section{B. Online Learning Environment And Discussion Forumn Participation}

Paper [5] suggests that in the online classroom, knowledge is primarily generated through the relationships and interactions among learners and instructors. Online learning systems are defined as an educational environment where instructors and students are separated from each other and involved in a two-way interaction using technology to mediate the necessary communication [6].

In a fully online course, students can only interact with other students and instructors via the use of information and communication technology. Interaction has long been a defining and critical component of the educational process. Online interaction among course participants is a critical feature of online teaching and learning [7]. Researchers of [8] states that online participation, measured as interaction with peers and teachers, has a positive effect on perceived learning, grades and quality assessment of assignments. Researchers affirm that student interaction is a strong predictor of learner achievement and development [9].

Discussion forums have frequently been used successfully as communication tools in online learning environments to facilitate interaction between students to share knowledge [10-12]. Discussion forums provide an effective opportunity to exchange ideas and share knowledge amongst learners and instructors [13, 14].

Researchers have argued that the benefits of quality engagement are not always achieved because of the inconsistent online participation [15]. Researchers of [16] classified online participation by grouping them as "Lurkers", "Members" and "Experts". The above mentioned models of student participation in online forums provide an overview for the expected student behavior which we will look for in our discussion forums.

Paper [17] identified student roles and instructional tasks as critical factors which influence the patterns of learner participation. Our intention is to find out the factors that lead towards the diverse student behavior for fully online introductory Computer Science/IT courses while also encouraging students to participate and learn.

\section{Quality Of Interaction And Participation}

Quality of online interaction has been investigated and measured by several researchers. A conceptual framework proposed in [18] defines the main criteria depending on which qualitative online interaction can be designed. While this framework looks at the quality of interaction related to the student participation, it does not provide guidelines about how learner-instructor interaction should be designed to ensure enhanced quality student interaction. In addition, the criteria in this framework were derived through research into blended learning environment. Concerning the role of instructors in an ongoing discussion, Researchers of [19] reported that the main responsibility of the instructors is to provide information; whereas [20] found out that the task is to enable effective interaction. These researchers report contradictory opinions among researchers on how instructors should be moderating a discussion forum which provides the backbone of a fully online course.

A clearly defined framework makes explicit to students the expectations of their engagement in discussions and thereby shapes that engagement. For that purpose we need to address how the issue of "quality of interaction" can be defined and what are the general criteria for quality online interaction for both students and instructors.

\section{Research Questions}

Paper [1] suggests that if participation lacks in sufficient quantity, quality, timing, and purpose then it is less likely that the learning objectives will be met through that activity.

We are interested in these aspects for fully online introductory computing courses. In particular, what factors actually affect student participation and what criteria are perceived as providing quality interaction by fully online students were investigated. Our research questions are:

RQ1: What factors affect the student participation in online discussion forums?

RQ2: What qualities of discussion are perceived as constructive by online students?

We aim to research and identify the criteria for quality interaction by both students and instructors as perceived by the students. Quality interaction influences learner satisfaction [21] and learning outcomes [22], hence it is important to recognize how students define this concept of quality interaction.

Online education is faced with an interesting paradox of growing demand and enrolment coupled by higher withdrawal and failure rates [23]. Our overall aim in the research for this paper is to identify which strategies should be followed to improve participation, engagement and hence overall results in online courses.

\section{Research Methodology And The OnLine COURSES}

We collected the data from four consecutive study 
periods where different changes were made by the instructors. In this paper, we analyze the data in the online discussion forums and report the impacts the changes have made to the student participation online. We also research whether the quality of participation was perceived as advantageous by students. We develop and administer a survey asking students their perceptions of the online discussion forums. The fully online environment is considered as primarily learner-centred, hence it is important to understand what type of posts are considered as "quality posts" by students so that they are they are benefitted through interaction. In doing so, we identify a set of guidelines for student interaction and instructor participation from the criteria which are highly valued by students for online participation.

\section{A. The Student Cohort And The Courses}

In order to conduct the research two fully online introductory Computing courses from Open Universities Australia (www.open.edu.au) are chosen. One of them is an Introduction to Programming course and the other is an Introduction to IT course. The Introduction to Programming course (Prog1, Prog2, Prog3, and Prog4) covers introductory concepts of programming through the use of two programming languages; Alice and Java. Students enrolled in this course are from the Bachelor of Technology and Master on Information Technology degrees.

Table 1. Overview of the Programming Courses

\begin{tabular}{|c|c|c|c|c|}
\hline Course & Prog1 & Prog2 & Prog3 & Prog4 \\
\hline $\begin{array}{c}\text { Number of } \\
\text { Students }\end{array}$ & 346 & 302 & 282 & 273 \\
\hline $\begin{array}{c}\text { Number of } \\
\text { Tutors (not } \\
\text { including the } \\
\text { instructor) }\end{array}$ & 0 & 2 & 2 & 2 \\
\hline $\begin{array}{c}\text { Ratio of } \\
\text { Students to } \\
\text { Instructor }\end{array}$ & $346: 1$ & $100: 1$ & $95: 1$ & $90: 1$ \\
\hline $\begin{array}{c}\text { Marks for } \\
\text { Group } \\
\text { Discussion }\end{array}$ & 0 & 5 & 5 & 0 \\
\hline $\begin{array}{c}\text { Assignments } \\
\text { Released }\end{array}$ & Periodical & $\begin{array}{c}\text { All in } \\
\text { week 1 }\end{array}$ & Periodical & Periodical \\
\hline Pass Rate & $48 \%$ & 52.86 & $48.74 \%$ & $46.43 \%$ \\
\hline
\end{tabular}

The Introduction to IT course (IT1, IT2, IT3 and IT4) covers general IT concepts e.g. computer fundamentals, operating systems and applications, internet and spread sheets. This course has students from various degrees including Bachelor of Technology, Business IT, Indigenous Studies, and Accountancy as well as the Master of Information Technology.

Both courses are conducted in fully online environments and there are absolutely no face-to-face classes. Both courses have online discussion forums where students are encouraged to participate and interact with each other. The instructor moderates the discussion forums and encourages questions and responses from all the online students enrolled in the courses. The instructor and tutors does not post any questions, but primarily uses the forum as a place for answering the individual questions of each student for the benefit of the class. A number of changes starting with the allocation of assessment marks for discussion, and including the timing of assignment releases and the provision of the number of tutors affecting the student: instructor ratio were made during these 4 study periods. An overview of the courses and the changes is presented in Table 1 for the Programming courses and Table 2 for the Introduction to IT courses.

Table 2. Overview of the Threads in the Discussion Forums

\begin{tabular}{|l|l|}
\hline Threads & Purpose \\
\hline Welcome and Introduction & $\begin{array}{l}\text { To allow students to introduce } \\
\text { themselves which would make } \\
\text { them known to each other } \\
\text { virtually and take a step forward } \\
\text { in creating a virtual community } \\
\text { of learners. }\end{array}$ \\
\hline General Discussion & $\begin{array}{l}\text { To allow students to ask and } \\
\text { respond to questions about the } \\
\text { general management of the } \\
\text { course. Discussion in this thread } \\
\text { mainly consisted of which } \\
\text { programming language they } \\
\text { should use and any problems in } \\
\text { installing software, issues } \\
\text { regarding navigating through } \\
\text { the online environment, issues } \\
\text { regarding how assessment } \\
\text { would be done in the courses. }\end{array}$ \\
\hline Feedback & $\begin{array}{l}\text { To allow students to discuss } \\
\text { weekly study materials. } \\
\text { Students were divided into } \\
\text { groups by the instructor and } \\
\text { assigned a separate tutor. } \\
\text { discuss queries regarding } \\
\text { assignments and exams. The } \\
\text { courses had separate forums for } \\
\text { each separate assignment and } \\
\text { exam. }\end{array}$ \\
\hline Assignment and Exam & $\begin{array}{l}\text { To allow students to provide } \\
\text { overall feedback about the } \\
\text { management and content of the } \\
\text { course. }\end{array}$ \\
\hline
\end{tabular}

Throughout all 4 study periods (SP), the one same instructor was in charge of both the courses. Apart from Prog1, when there were no tutors, the instructor was assisted by a number of tutors. All the course materials were uploaded into Blackboard before the start of the study periods. Students were provided with comprehensive directions regarding which topic would be covered in which study weeks. Assignments were uploaded into Blackboard, the Learning Management System and deadlines for assignment submissions were advertised clearly both in the course guides and in the General discussion threads. Weekly synchronous chat 
sessions were organized by the instructor or tutors to discuss the study material for that week. These chat sessions were organized via Elluminate, a synchronous discussion tool with text, audio and video facilities which works in conjunction with Blackboard storing the recorded sessions near the discussion forums. Student attendance was very low in these chat sessions primarily because of their work and time constraints. Another reason could be the location of the students as they were located in many different parts of rural Australia and also spread out in several different countries of the world. Several threads (Table 3) were created by the instructor in all four study periods for both courses to allow students to communicate via the online environment. On average, the instructor and tutors checked the discussion boards and responded once daily throughout the study periods.

Table 3. Overview of the IT Courses

\begin{tabular}{|c|c|c|c|c|}
\hline Course & IT1 & IT2 & IT3 & IT4 \\
\hline $\begin{array}{c}\text { Number of } \\
\text { Students }\end{array}$ & 299 & 406 & 154 & 242 \\
\hline $\begin{array}{c}\text { Number of } \\
\text { Tutors (not } \\
\text { instructor) }\end{array}$ & 2 & 3 & 3 & 2 \\
\hline $\begin{array}{c}\text { Ratio of } \\
\text { Students to } \\
\text { Instructor }\end{array}$ & $100: 1$ & $100: 1$ & $40: 1$ & $80: 1$ \\
\hline $\begin{array}{c}\text { Group } \\
\text { Discussion } \\
\text { Marks }\end{array}$ & 10 & 5 & 5 & 0 \\
\hline $\begin{array}{c}\text { Assignments } \\
\text { Released }\end{array}$ & Periodical & All in & Periodical & Periodical \\
\hline Pass Rate & $49 \%$ & $57.64 \%$ & $48.75 \%$ & $54.15 \%$ \\
\hline
\end{tabular}

Assignments were normally released periodically for the both the courses i.e. assignment 2 was released during the weeks when assignment 1 was due and assignment 3 was released in the weeks when assignment 2 was due. However all the assignments were released together and during the first weeks for both Prog2 and IT2.

This is a longitudinal study with data from 8 cohorts of students collected over 4 study periods. With ethics approval, data was collected from the discussion forums in Blackboard, the University's Learning Management System, throughout study periods starting from September 2009 until November 2010. As itemized in Tables 1 and 2, a number of changes were made regarding how the courses were managed over this time.

To determine the factors that impacted the student activity and achievement, the number of times students posted in the discussion forums throughout the study periods was recorded. We graphed the number of posts against study weeks to analyst the trend of participation. We also analyzed the student posting rates in each of the forums to investigate the distribution of participation. At the end of the study period, assignment and final examination results for each student were recorded. Using these assessment results we investigated whether the alterations in the course management had actually affected the student participation online and whether it had any impact on the results.

\section{B. The Survey}

We designed a survey to ask the online students about the discussion forums, what they liked and what they might like to change or include, whether they aided their interaction and learning or not. The survey consisted of three parts:

(1) Background information: These asked participants for some general information regarding age, language and whether or not this was their first online course.

(2) Closed statements: These asked participants about their experience of the usage of the fully online environment, the mobility of the courses and the role of the instructors. These statements included criteria from the framework of [18] and students were asked to say whether they agreed or disagreed with them.

(3) Open-ended questions: These questions provided the major source of data to investigate what attributes the participants perceived for a discussion to be high in quality and beneficial to their learning.

Through qualitative data analysis of the responses to the open ended questions, we attempted to uncover criteria for quality and productive discussion between students and the instructors.

The open ended responses in the survey were processed using the grounded theoretic approach [24] i.e. open, axial and selective coding [25-26] so that information relevant to the research could be extracted. All the responses were loaded into NVivo 8 software for investigation through open, axial and selective coding. We identified around 45-50 criteria by analyzing the data at the end of the open coding phase. Each separate concept in the data was labelled and similar ideas were grouped together and re-labelled. Following open coding, the next step was axial coding, where the aim was to assemble the coding categories into larger conceptual groupings [27]. The two major categories which emerged were student participation and instructor contribution. Each category consisted of a number of criteria and subcriteria. This process was repeated until no additional categories were identified and all the data had been analyzed. The third and final coding step was selective coding. Again, the data were re-examined and the prior coding and grouping was revisited and verified or changed as required. This set of emergent criteria is presented in the "findings" section.

\section{DATA ANALYSIS AND FINDINGS}

Fig. 1 and 2 provide an overview for the average number of posts per student each week in the Programming and IT courses respectively over the four study periods.

Weeks 8 and 11 saw more posts in the Programming 
course which is when Assignment 3 was released and due for submission. In general, IT1, IT2 and IT3 had more posts throughout than IT4. Group participation was assessed in those periods for IT1, IT2, and IT3 and marks were assigned which might have triggered more students to participate online.

The noticeable issue is that number of posts in IT4 was very low throughout the study period which might be the result of removing assessment marks for participation. The number of posts decreased around week 7 for all the study periods and remained the same afterwards.

A. Posts by Forums

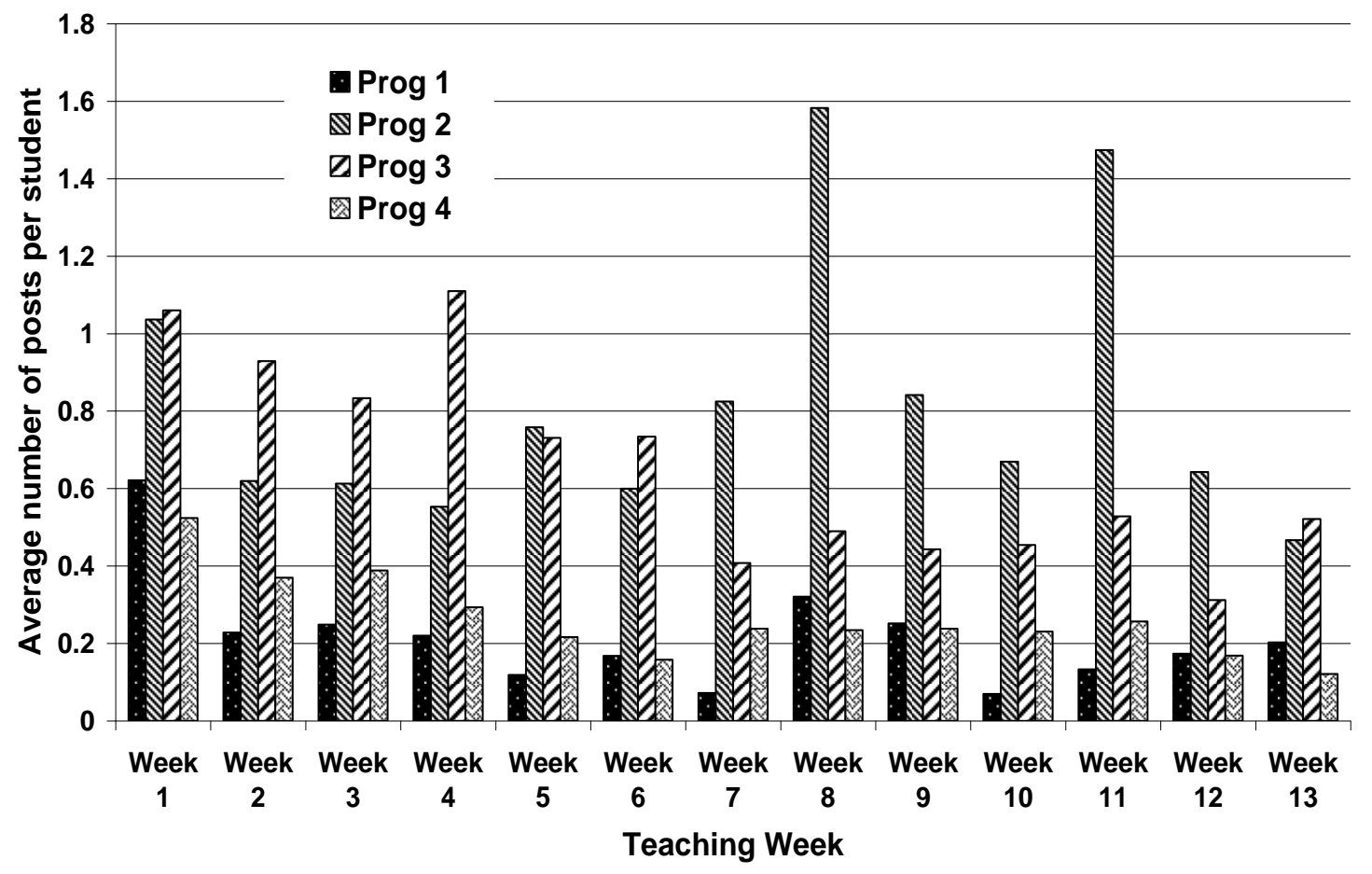

Fig.1. Posts by week (Introduction to Programming)

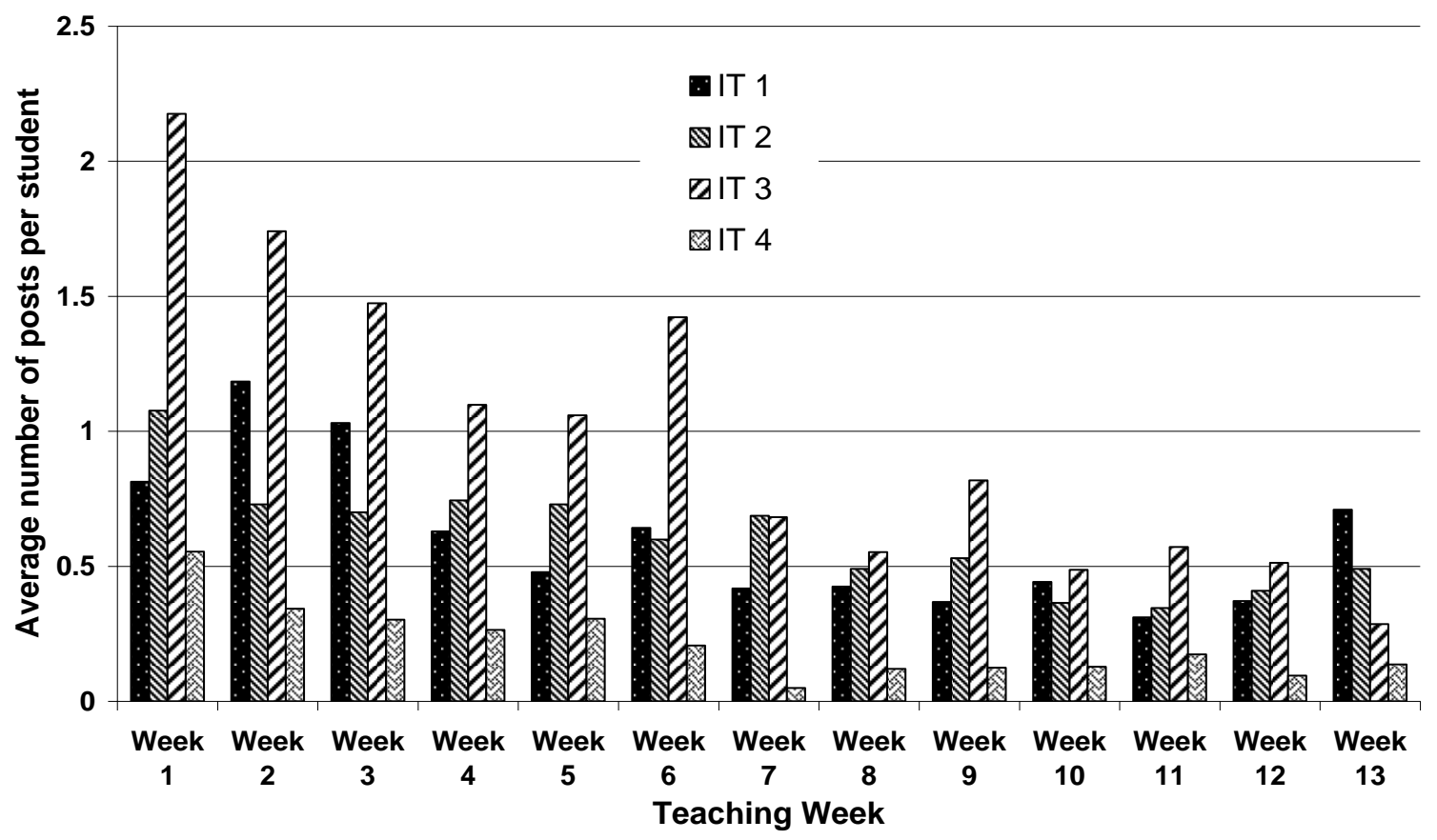

Fig.2. Posts by week (Introduction to IT) 


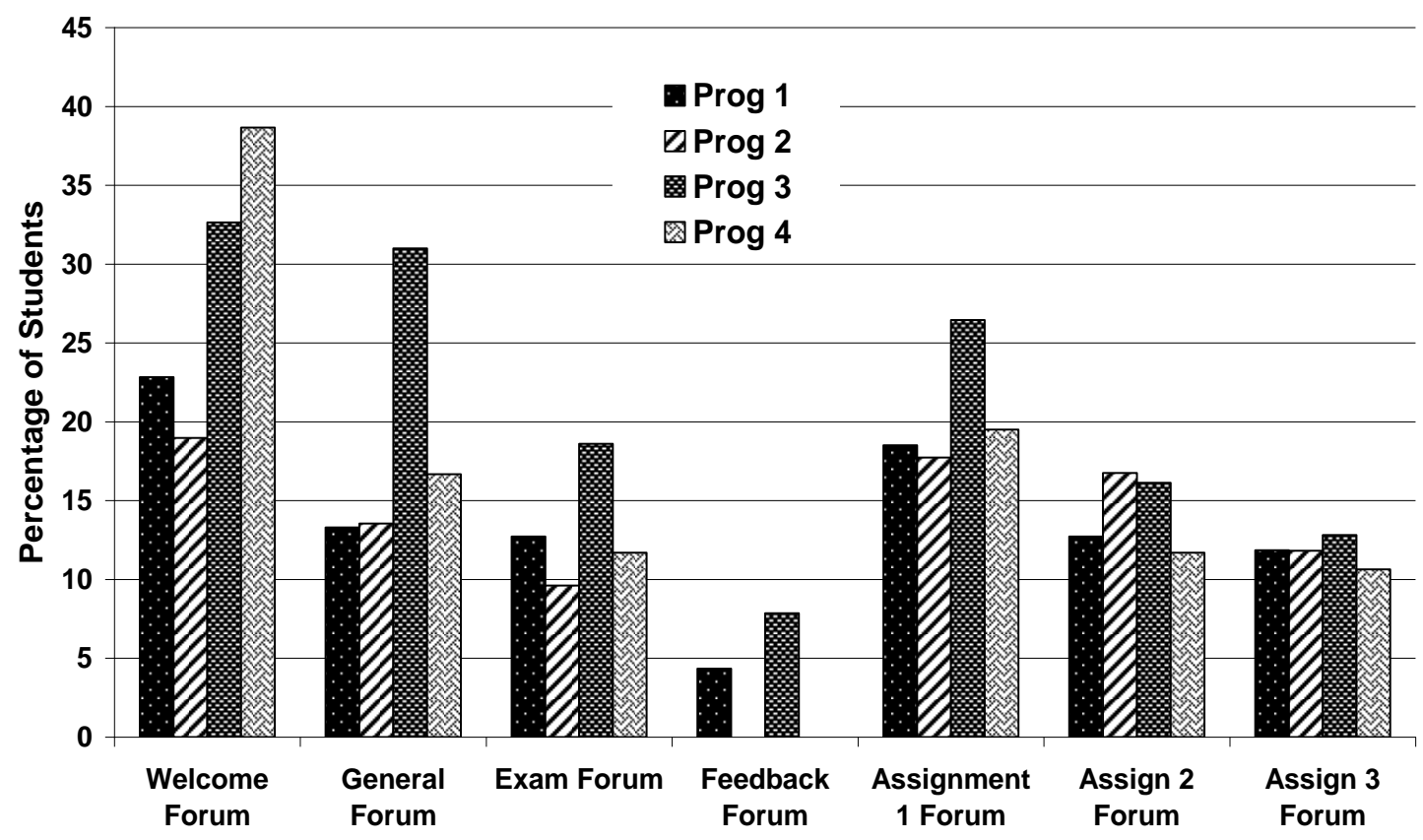

Discussion board Forum

Fig.3. Percentage of Students Posting in the Programming Courses in Different Forums

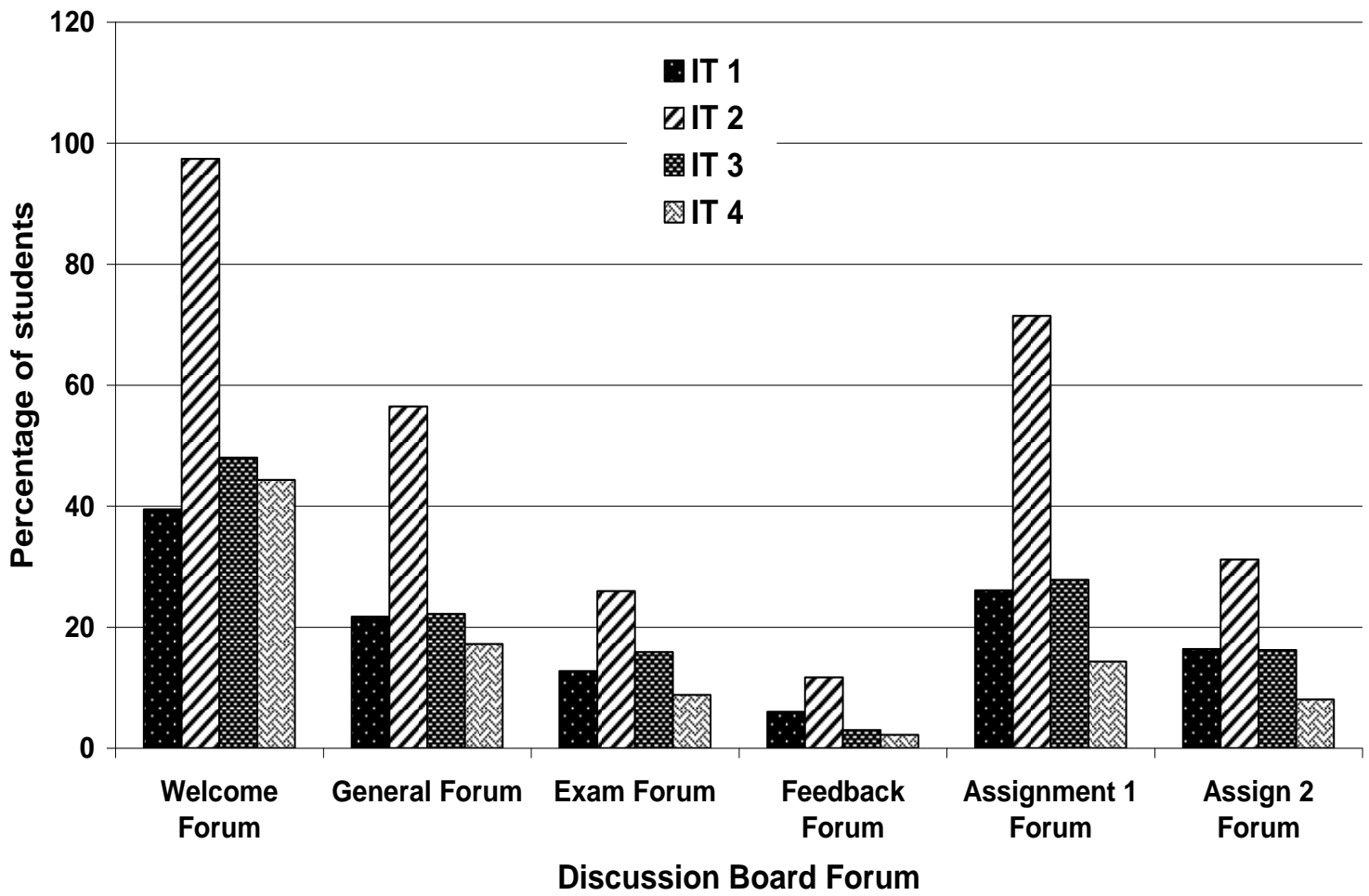

Fig.4. Percentage of Students Posting in the IT Course in Different Forums

Fig. 3 and 4 provide the percentages of students that posted in different forums in the Programming and IT course respectively. Both the Fig.s 3 and 4 show that the highest percentage of the students who posted to the forum actually posted in the "Welcome and Introduction" forum where they tried to build a community of learners by "virtually" meeting each other. The second most populated forums were the Assignment 1 and General forums. In has been noticeable that most of the online students employed a goal based learning approach where they started doing the assignments from the very first week and tried to discuss the study material that is relevant to the assignments. This approach made the Assignment 1 forum more populated than others. 
In general the number of students who posted in the assignment forums ranged in between 10-20\%. However this number was around $70 \%$ for assignment 1 in IT2 which is high compared to other assignments throughout the study periods. All the assignments were released altogether in the first week in IT2 and it was noticeable that, students posted about both assignments in the assignment 1 forum right immediately after the assignment specifications were released. As a result much confusion was created.

\section{B. Assessment Components Received and Passed}

Student satisfaction and dropout rates are the key determinant factors for the success of any course [28]. More than 50\% students dropped out of the online IT/Programming courses compared with $10 \%$ in standard on-campus courses [29].

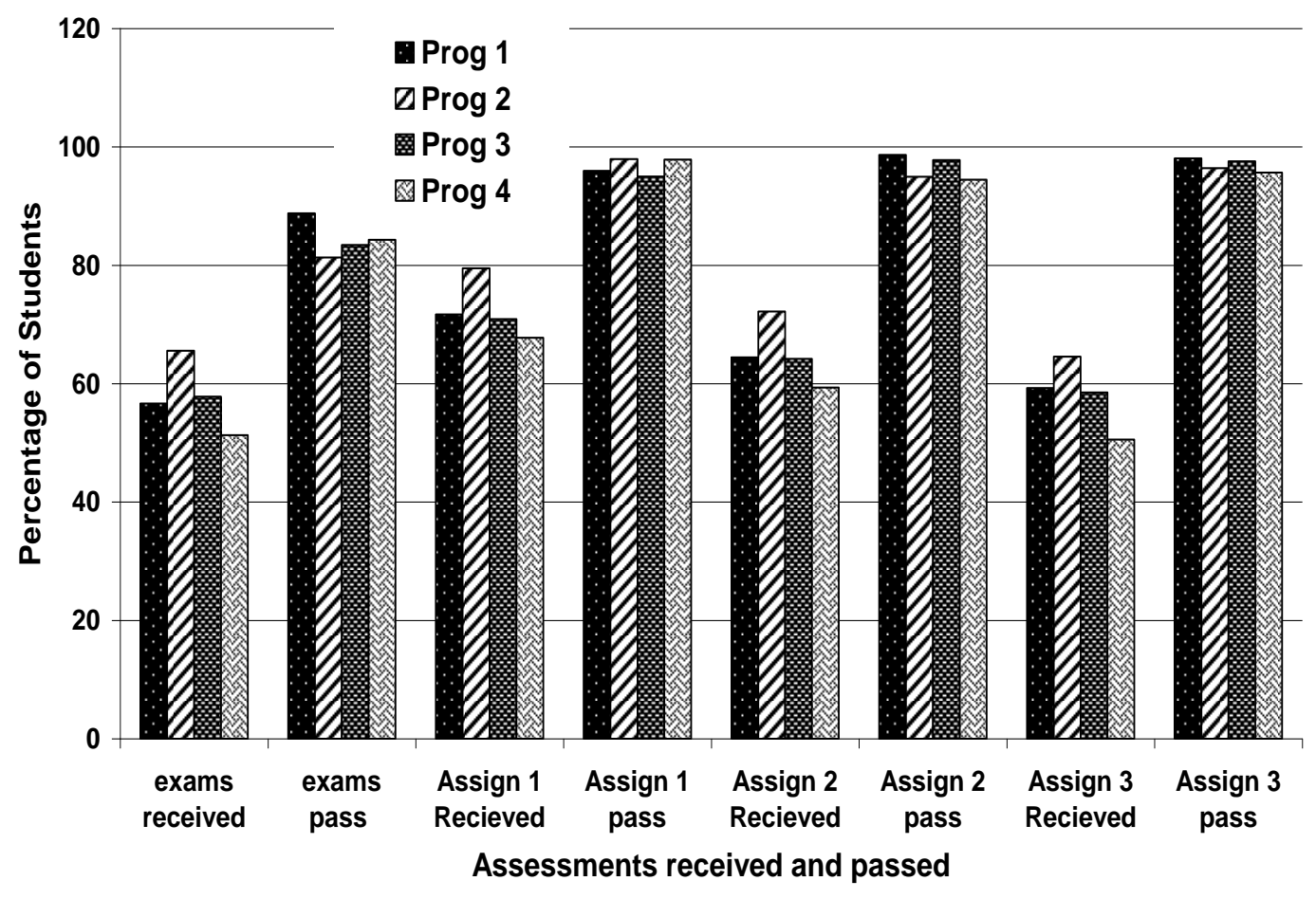

Fig.5. Percentage of Students Completed the Assignments, Exams and Passed In the Programming Course

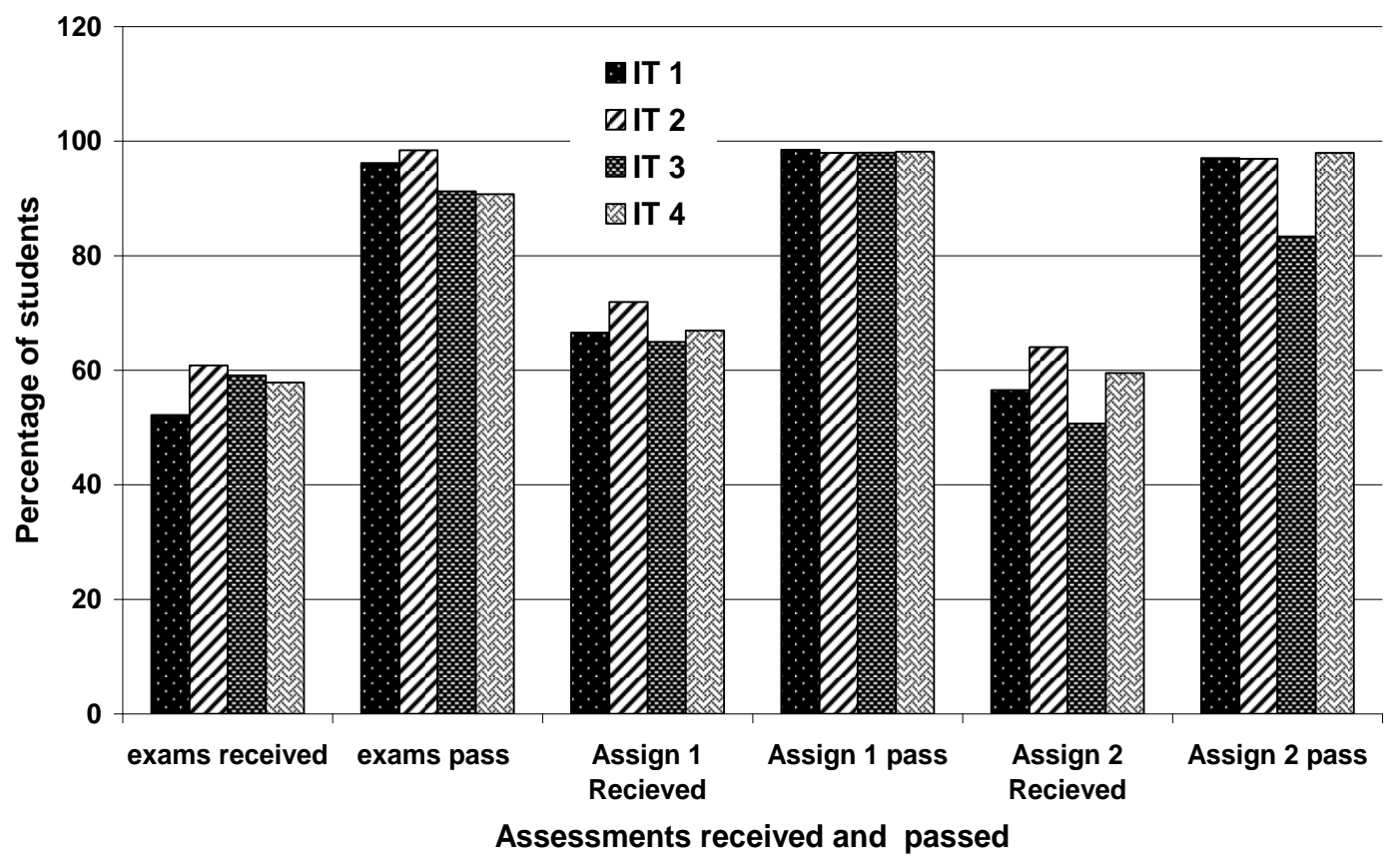

Fig.6. Percentage of Students Submitted Assignments, Exams and Passed in the IT Courses 
The numbers of students who submitted the assignments and appeared in the final exam are presented as percentages in Fig. 5 (Programming) and 6 (IT). The Figs show that $70-80 \%$ students submitted assignment 1 , but this percentage decreases for the later assignment(s). Only $50-60 \%$ of students submitted the final assignments and sat for the exam. This trend remained same for both the Programming and IT courses. Almost 95\% of the students who submitted the assignments received a pass mark while this number was approximately $80 \%$ for the final exam.

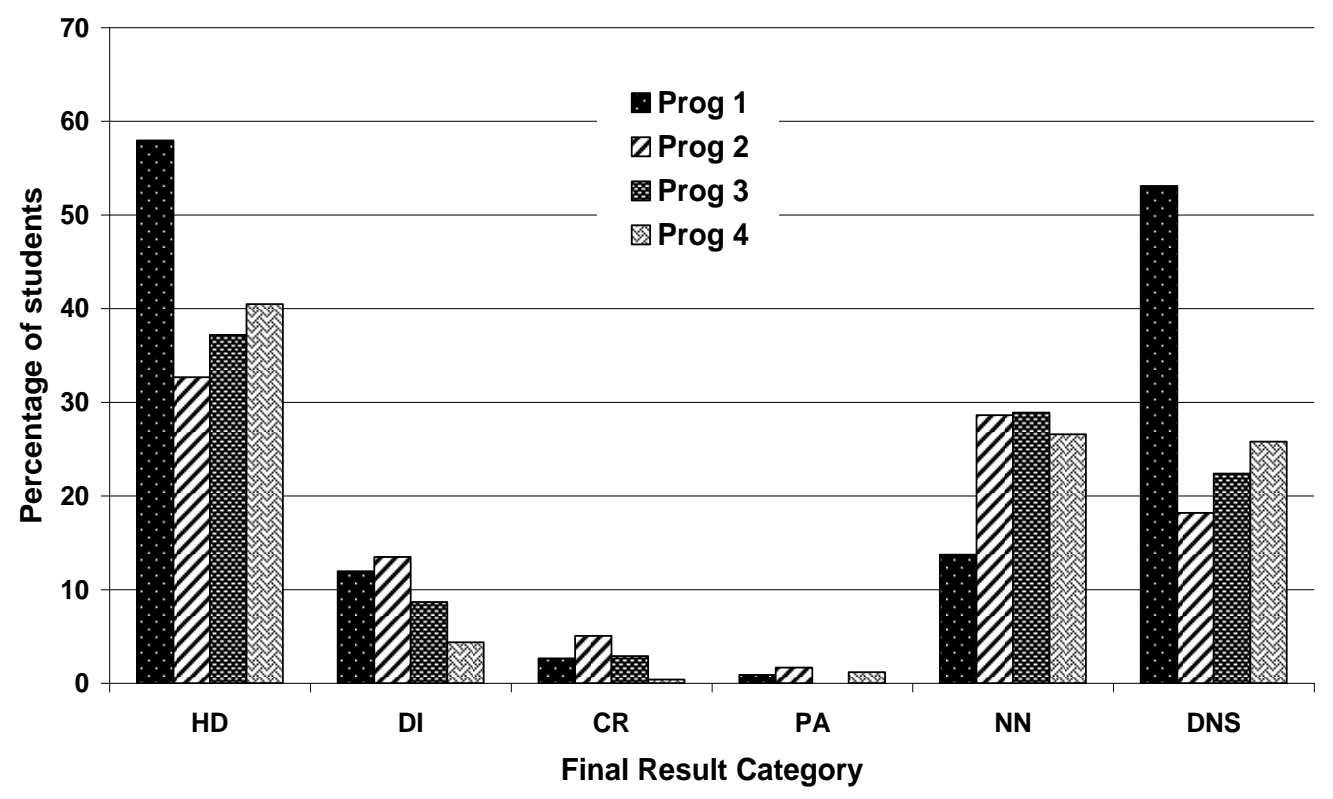

Fig.7. Grades Achieved in the Programming Course

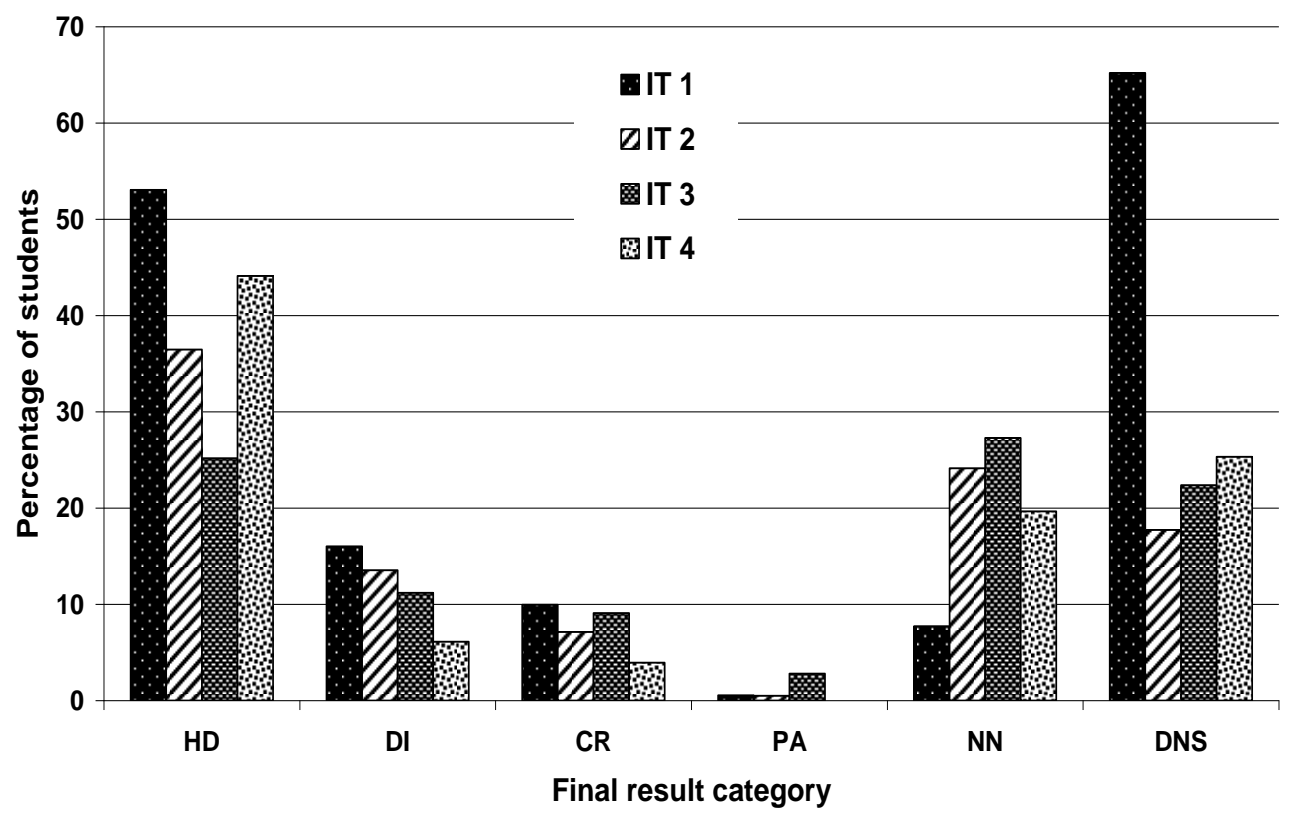

Fig.8. Grades Achieved in the IT Course

\section{Overall Results}

Finally, Fig. 7 represents the grades achieved by the students in the Programming course over the 4 study periods. On average around $30-40 \%$ of students achieved
(High Distinction) HD results in the course out of those who continued till the end with the number being close to $60 \%$ for Prog1. This trend was similar for the IT courses and is presented in Fig. 8. The highest rate of HD was 
achieved during IT1 whilst the lowest HD rate was $25 \%$ in period IT3.

The noticeable factor is that almost $50-60 \%$ students in both Prog1 and IT1 received "DNS" which means they did not submit any assignments and also did not sit for the final exam. This rate dropped to around $20-25 \%$ for Prog4 and IT4

\section{Survey Data Analysis}

We designed, administered and analyzed a survey for the students in four of the chosen courses. The criteria derived from our analysis represents what the participants regarded as quality and productive discussions between students and instructors because this was what they contributed by actually participating in the forums.

The background data from the survey revealed that the participants were primarily undergraduate students in the age range 20-40. These were the first online courses for $80 \%$ of the students.

Table 4. Percentage of Responses to Closed Survey Questions

\begin{tabular}{|c|c|c|c|c|c|}
\hline Criteria Statements & SD & $\mathrm{D}$ & $\mathrm{N}$ & $\mathrm{A}$ & SA \\
\hline $\begin{array}{l}\text { S1. The setting and structure of the online discussion forum was easy to follow } \\
\text { initially }\end{array}$ & 0 & 7.7 & 15.4 & 61.5 & 15.4 \\
\hline $\begin{array}{l}\text { S2. During the use of the online discussion forum do you consider that you are } \\
\text { part of a community of learners }\end{array}$ & 0 & 15.4 & 7.7 & 53.8 & 23.1 \\
\hline S3. Did you find that being able to post any time or anywhere as an advantage & 0 & 0 & 7.5 & 23.4 & 69.1 \\
\hline $\begin{array}{l}\text { S4. Do you feel the online discussion forum gave you more time to reflect on } \\
\text { what you wanted to ask/answer allowing you to process your ideas better }\end{array}$ & 0 & 0 & 7.7 & 53.8 & 61.5 \\
\hline $\begin{array}{l}\text { S5. Do you prefer working in a team to collaborate rather than an individualistic } \\
\text { approach, working on your own }\end{array}$ & 0 & 38.5 & 0 & 30.8 & 30.8 \\
\hline $\begin{array}{l}\text { S6. The online discussion forum has been useful for learning and understanding } \\
\text { of concepts or a subject }\end{array}$ & 0 & 7.5 & 0 & 53.8 & 38.7 \\
\hline $\begin{array}{l}\text { S7. Do you feel it is an advantage if all students participate equality and } \\
\text { consistently }\end{array}$ & 7.7 & 23.1 & 38.5 & 23.1 & 7.7 \\
\hline $\begin{array}{l}\text { S8 .Do you feel students should raise new issues/directions about the topic of } \\
\text { discussion in the forum }\end{array}$ & 0 & 7.7 & 23.1 & 53.8 & 15.4 \\
\hline S9. Do you feel students should justify their opinions through proper references & 5.5 & 30.8 & 25.3 & 38.5 & 0 \\
\hline $\begin{array}{l}\text { S10. Do you feel students should bring in outside knowledge as example while } \\
\text { discussing about a topic }\end{array}$ & 0 & 7.7 & 30.8 & 46.2 & 15.4 \\
\hline S11. Do you feel students should critically assess each other's posts & 7.7 & 23.1 & 38.5 & 23.3 & 7.5 \\
\hline $\begin{array}{l}\text { S12. Do you feel students should use informal language or social cues sometimes } \\
\text { to lighten the discussion }\end{array}$ & 0 & 7.7 & 7.7 & 46.2 & 38.5 \\
\hline S13. Do you feel instructors/tutors should be actively involved in the discussion & 0 & 0 & 0 & 53.8 & 46.2 \\
\hline S14. Do you want instructors/tutors to answer your questions rather than students & 0 & 0 & 46.2 & 23.1 & 30.8 \\
\hline $\begin{array}{l}\text { S15. Do/did you ever feel that this online environment hampered your efforts to } \\
\text { understand/learn a specific concept in the subject }\end{array}$ & 30.8 & 23.1 & 15.4 & 30.8 & 0 \\
\hline $\begin{array}{l}\text { S16. Do you feel that you are learning the necessary skill of problem solving } \\
\text { through this online environment }\end{array}$ & 0 & 0 & 23.1 & 53.8 & 23.1 \\
\hline
\end{tabular}

\section{E. Responses to Closed Questions}

From Table 4, it is clear that a high percentage of respondents felt at ease with the structure of the online discussion forums and considered learning online to be an advantage (see for example the percentage who agreed with S1, S2, S3 and S4).

The most emphatic result from the survey was for statement S13 where respondents emphasized the need for instructors to be actively involved in the discussion forum assisting students. A high percentage of students considered themselves to belong to a virtual community of learners and felt that a productive discussion forum can be beneficial in achieving their learning goals (S2, S6). Survey respondents considered the mobility of learning "any time anywhere" as an advantage (S3) and felt that the asynchronous nature of online discussion provided them with time to think and reflect on their learning better (S4).
There were some contradictions regarding the use of language in the forums (S9, S11, S12); however most felt that limited use of informal language should be practiced during online discussion. Investigating responses to S15 indicates that around $30 \%$ respondents considered that the overall online environment hampered their efforts to understand and learn concepts in their courses.

\section{F. Student Participation}

The final section of the survey contained open ended questions which were analyzed to investigate what types of posts are valued as quality and productive participation by the students and instructors. Table 5 presents the set of criteria that appeared through data analysis along with the number of times, $\mathrm{N}$, that they were mentioned by the respondents as valuable criteria for student participation and typical quotes for each criterion. 
Table 5. Criteria derived from grounded theory relating to student participation where $\mathrm{N}$ is the number of times they appeared in the survey responses

\begin{tabular}{|c|c|c|c|}
\hline \multicolumn{2}{|l|}{ Criteria } & $\mathbf{N}$ & Quotes \\
\hline \multicolumn{2}{|c|}{ Asking Questions } & 40 & $\begin{array}{l}\text { "I get a lot from other students' questions, as they ask questions sometimes that } \\
\text { I haven't even thought of yet." }\end{array}$ \\
\hline \multirow[t]{3}{*}{$\begin{array}{l}\text { Answering } \\
\text { Questions }\end{array}$} & $\begin{array}{l}\text { Straight and in } \\
\text { detail }\end{array}$ & 39 & $\begin{array}{l}\text { "Just simple help by answering questions that arise and just general discussion } \\
\text { of the topic." }\end{array}$ \\
\hline & With example & 7 & "A little more detail, ability to paste code so that it is formatted correctly." \\
\hline & Justification & 8 & "Just gets a little confusing when incorrect information goes up." \\
\hline \multicolumn{2}{|c|}{ Clarification } & 22 & $\begin{array}{l}\text { "Most of my posts are queries for my information if I am not sure of the } \\
\text { concept or do not understand it." }\end{array}$ \\
\hline \multicolumn{2}{|c|}{ Critical discussion of contribution } & 5 & $\begin{array}{l}\text { "Usually if posting about a question, i give my thoughts to the answer and invite } \\
\text { comment from others as to the validity of my answer, if giving an answer to } \\
\text { someone else's question i offer my thoughts and where i derived information } \\
\text { from so they can check also." }\end{array}$ \\
\hline \multicolumn{2}{|c|}{ Ideas from interaction } & 7 & $\begin{array}{l}\text { "I get a lot from other students' questions, as they ask questions sometimes that } \\
\text { I haven't even thought of yet." }\end{array}$ \\
\hline \multicolumn{2}{|c|}{ Providing feedback } & 2 & $\begin{array}{l}\text { "Can complement, issue feedback, he lp, update, keep informed, share } \\
\text { information, see how other students think and feel about a particular topic or } \\
\text { discover something I didn't know to think about relating to...." }\end{array}$ \\
\hline \multicolumn{2}{|c|}{ Sharing own experience and knowledge } & 15 & $\begin{array}{l}\text { "Want to see how others have approached the question or problem and solved } \\
\text { it." }\end{array}$ \\
\hline \multicolumn{2}{|c|}{ Suggesting multiple solutions } & 2 & "More than one solution makes me think in different dimensions." \\
\hline \multicolumn{2}{|l|}{ Relevance } & 31 & "Relevant to topic in question." \\
\hline \multicolumn{2}{|c|}{ Consistency of participation } & 5 & "Where the students are actually contributing." \\
\hline \multicolumn{2}{|c|}{ Informal Posts } & 7 & "Subject topics and some light hearted stuff too." \\
\hline
\end{tabular}

Almost $70 \%$ of the survey respondents mentioned they wanted to see questions being asked in the discussion forums which lead to productive discussion. Almost all of the survey respondents emphasized the value of answering questions which assists others to gain knowledge and inspire a productive discussion. Clarification refers to explaining the posts in a clear and concise way so the meaning can be easily understandable by everyone. This is one of the most important criteria for participating in any discussion forum. Almost all the survey respondents emphasized the importance of having relevant discussion in the forum. Students wanted instructors to continuously monitor the discussion forum so that the participation is always about relevant topics.

Table 6. Criteria related to Instructor Contribution where $\mathrm{N}$ is the number of times they appeared in the survey responses and the third column provides some typical quotes

\begin{tabular}{|l|c|l|}
\hline Criteria & $\mathbf{N}$ & Explanation and Quote \\
\hline $\begin{array}{l}\text { Administrative guideline or } \\
\text { technical assistance }\end{array}$ & 19 & $\begin{array}{l}\text { "For the open forums just a regular reminder about the types of posts preferred and } \\
\text { occasional purging of irrelevant material." }\end{array}$ \\
\hline Declaration of expectations & 2 & $\begin{array}{l}\text { "Make it really clear from day one exactly how things work (for that subject in particular), } \\
\text { what is required and desired and how to make it work well for everyone." }\end{array}$ \\
\hline $\begin{array}{l}\text { Periodic intervention to direct and } \\
\text { extend discussion }\end{array}$ & 60 & $\begin{array}{l}\text { "Students can maintain online discussion with no teacher intervention at all but I do not } \\
\text { agree that this is a good thing all the time as some students can project an air of authority } \\
\text { but be basically talking rubbish." }\end{array}$ \\
\hline Promoting deep learning & 5 & $\begin{array}{l}\text { "Tips and advice about certain part of assignments, direction to information regarding } \\
\text { your questions so you can check it out yourself." }\end{array}$ \\
\hline Providing direct answers & 17 & $\begin{array}{l}\text { "I would like to see the instructors to be more proactive and to answer the questions } \\
\text { clearly." }\end{array}$ \\
\hline Providing feedback & 26 & $\begin{array}{l}\text { "To supply expert information and correct incorrect information put forth by myself and } \\
\text { other students." }\end{array}$ \\
\hline Feedback with example & 2 & "Marking structure, where some useful information can be found i.e E-Books." \\
\hline
\end{tabular}

Table 6 presents the criteria revealed through data analysis along with the number of times they appeared in the survey responses. These criteria provide an overview of the ideal role of the instructors in discussion forums as perceived by the students.

Almost all the survey participants mentioned that they 
wanted consistent instructor intervention to direct the discussion. Consistent intervention by the instructor keeps the discussion on track. High numbers of participants wanted periodic instructor feedback. 26 respondents mentioned that it is important for the instructors to provide feedback on their work or comments, as it inspired them to work ahead or change direction while solving a problem. Administrative guidelines were regarded very highly by the participants. 19 participants regarded this criterion very highly as it provides the initial guiding principle for the course.

\section{Discussion}

The data analysis and findings section has provided an overview of the number of students postings in the different discussion board threads, the number of postings throughout the study period, dropout rates and the grades they achieved in different assessments. The focus of this research was on the participation patterns and quality of interaction of the students and instructors in the discussion forum. By analyzing the survey responses, several criteria were identified for designing quality online participation.

\section{A. Impact of Assessment}

Researcher of [30] suggests that consistent participation enhances student learning and the strongest motivator for participation is to provide some incentive as students generally value assessment. From Fig. 1, it is visible that first and second study periods in 2010 in the programming courses saw more participation than other periods in 2009. Similarly from Fig. 2, it is evident that IT1, IT2 and IT3 saw more participation from the students than IT4. This leads us to conclude from this data that providing assessment marks for contributing to the discussion forum does have an impact on the participation of fully online students. Other authors have also found the incorporation of assessment of participation in online discussion forums to have a positive impact on learning outcomes as well [31]. Further research is required to identify the impact of assessment on interaction. One way to carry out that research would be to conduct surveys with the students on what they think about the forums being assessed. The responses can then be compared to the actually posting rate and grades to have a better understanding of the impact.

\section{B. Difference in Tutor Support}

Previously we found that difference in the number of instructors and tutors supporting the forum can impact student participation [32]. This is one of the major factors that [33] identified as motivators for online participation. The student-instructor ratio was around 80-100:1 for most of the study periods apart from Prog1 (346:1) and IT3 (40:1). As the ratio was only 40:1 in IT3, instructors were able to provide more feedback and generate more discussion. This is evident from Fig. 2, which shows the average number of posts was consistently higher than for any other study periods.

The impact of this difference was not noticeable in the grades and the dropout rates of the students. The rate of "HD" and "DNS" was highest in Prog1, where there was no tutor support. However the pass rate in the IT course in IT3 was lower compared to other periods even though the student-instructor ratio of 40:1 was the lowest. Hence we have found that the quality of instructor and tutor support is more important than the quantity of feedback. The way instructors and tutors administrate and moderate the discussion forums should be investigated and future research would be benefit from such investigation.

\section{Quality of Interaction}

Survey respondents favored the criteria that allowed them to gain, share, deepen and expand knowledge. A number of criteria in the area of cognitive skills, use of both formal and informal language and frequency of participation were evident. Criterion such as justification of posts, clarification of ideas, critical discussion of contribution, and suggesting multiple solutions were valued highly by the students.

The main emphasis was on asking and answering questions. Research done so far analyzing criteria for online participation [14], largely focuses on how to answer questions and not on how the answers can be justified. Most of the criteria provide a guideline on how quality responses should be posted in online forums. Students highly valued the importance of asking questions and how it triggers the quality of discussion. For quality discussion to take place, quality questions need to be asked.

Our data analysis indicates that periodic feedback from the instructors is always valued highly by students which keep the discussion on track. Paper [34] suggests that periodic feedback can encourage meaningful dialogue, increase collaboration, peer and self-evaluation and create a sense of community for a shared learning purpose. It can be summarized that handing students the responsibility of directing discussion is not always the best option and instructors should be in control of the discussion at all times through an active presence. Students also wanted direct answers from instructors; however it falls to the instructor of the course to draw the balance between these two criteria of answering direct questions and providing clues or hints while moderating discussion.

Investigation of our data has shown that it is important to provide administrative or technical guidance early in fully online courses. Researchers [35] state that, computing students are at significant risk when attempting an online course compared to traditional classroom students because of the lack of interaction. Students need to know which software to install and guidance on how to install it. Hence clear and detailed guidelines are essential to assist the students to customize their fully online environment for learning. Instructors should declare early in the course their expectations of the students regarding how to participate and acquire the 
best out of the discussion forum. This declaration may consist of directions regarding how many and how often students should post in the discussion board, what should be the pattern of their contribution, how the students should approach the subject and in general what is expected of them. These findings emphasize the active involvement of the instructors in controlling learning processes which can help learners improve their ability to effectively use resources and strategies.

\section{CONCLUSION}

This paper has compared the course management, student activity and achievement in two fully online courses throughout four study periods. The overall research aim was to identify and investigate the factors that lead to effective online participation in fully online introductory Computer Science and Information Technology (IT) courses. A major focus of this paper has been to analyze the empirical data obtained from four successive instances of two fully online courses and survey the students involved to identify criteria for encouraging participation and engagement in the online discussion forums.

Results of our data analysis explain how student activity i.e. participation patterns differ from period to period in response to the alterations made in course management. Assigning assessment marks for discussion does play an important role in increasing participation, and so quantity and not necessarily quality of student contributions affects student postings and results. Further research is required to investigate the issue of "quality" and "quantity" of participation. We also found that there is a high dropout rate in both the online courses but most of the students who do continue in the courses achieve excellent HD results.

There are eleven criteria that came out of the qualitative data analysis which should be practiced by students while communicating online in order to acquire the best out of their interaction. Posts asking and answering questions, clarification and relevance to the topic of discussion were the most highly valued by our participants.

Data analysis also revealed the ideal role of an online instructor in discussion forums and the eight criteria that instructors can follow to achieve that goal. Almost all the survey respondents highly valued periodic intervention by the instructors to direct and extend discussion. Providing feedback and administrative guidelines or technical assistance and answering questions were also high on the list for the ideal role of instructors. These criteria highlight the dependency of the students on the instructors in these fully online computing courses.

\section{REFERENCES}

[1] V.P. Dennen,"From message posting to learning dialogues: Factors affecting learner participation in asynchoronous discussion", Distance Education, 26:1, pp: 127-148, 2005.
[2] D. Nandi, M. Hamilton \& J. Harland, "What Factors Impact Student - Content Interaction in Fully Online Courses" I.J. Modern Education and Computer Science, 2015, 7, 28-35 Published Online July 2015 in MECS (http://www.mecs-press.org/) DOI: 10.5815/ijmecs.2015.07.04.

[3] M. Dominic, S. Francis, \& A. Pilomenraj, "E-Learning in Web 3.0.", I.J. Modern Education and Computer Science, 2014, 2, 8-14 Published Online February 2014 in MECS (http://www.mecs-press.org/) DOI: 10.5815/ijmecs.2014.02.02.

[4] P. Zhang, L. Goel,'Is E-Learning for everyone? An international-external framework of E-learning initiatives", Journal of Online Learning and Teaching, Vol: 7, No: 2, pp: 193-205, June, 2011.

[5] G. Falloon "Exploring the virtual classroom: What student need to know (and teachers should consider)", Journal of Online Learning and Teaching, Vol: 7, No: 4, pp: 439-451, December, 2011.

[6] C.N. Gunawarda, M.S. McIsaac, "Distance Education. In: D.H. Jonassen, editor", Handbook of research for educational communications and technology, Lawrence Erlbaum Associates Inc Publishers, Vol. 2, 2004, pp: $355-$ 395.

[7] D. Gosmire, M. Morrison, J.V. Osdel, "Perceptions of interactions in online courses", Journal of Online Learning and Teaching, Vol: 5, No: 4, December, 2009, pp: 609-617.

[8] S. Hrastinski, "What I online learner participation?A literature review", Computers and education, Vol: 51, pp: 1755-1765.

[9] K.Q. Baker, K.E. Spiezio, K. Boland, "Student engagement: transference of attitudes and skills to the workplace, profession and community", The IndustrialOrganizational Psychologist, 42(2), 2004, pp: 101-107.

[10] P.A. Rovai, Building sense of community at a distance. International Review of Research in Open and Distance Learning: 3, 1, 2002.

[11] J. Bradshaw, L. Hinton, "Benefits of an online discussion list in a traditional distance education course", Turkish Online Journal of Distance Education, 5(3). Accessed 1/8/09.http://tojde.anadolu.edu.tr/tojde15/articles/hinton.h tm, 2004.

[12] R. T. Berner, "The benefits of bulletin board discussion in a literature of journalism course", The Technology Source, Sep/Oct.http://technologysource.org/article/benefits_of_b ulletin_board_discussion_in_a_literature_of_journalism_c ourse, 2003.

[13] M. Tallent-Runnels, J. Thomas, W. Lan, S. Cooper, T. Ahern, S. Shaw, X.Liu, (2006). "Teaching Courses Online: A Review of the Research:, Review of Educational Research, Vol: 76, no. 1, pp 93-135, 2006.

[14] S. Levine, "The online discussion board", New Directions for Adult and Continuing Education, Vol: 2007, No: 113, pp: 67-74.

[15] M. Guzdial, K. Carroll, "Explaining the lack of dialogue in computer- supported collaborative learning", Computer Supported Collaborative Learning Conference, CSCL 2002.

[16] K. O. Johnson, "The Online Student: Lurking, Chatting, Flaming and Joking". Sociological Research Online, Volume 12, Issue 6, 2007, accessed from http://www.socresonline.org.uk/12/6/3.html.

[17] S. Vonderwell, S. Zachariah, "Factors that influence participation in online learning", Journal of Research on Technology in Education, Vol: 38(2), 2005, pp: 213-230. 
[18] D. Nandi, S. Chang, S. Balbo, "A conceptual framework for assessing interaction quality in online discussion forums", In Same Places, Different Spaces, Proceedings ASCILITE, Auckland, New Zealand, 2009. http://www.ascilite.org.au/conferences/auckland09/procs/ Nandi.pdf.

[19] G. Davidson, V. Shivers, "Frequency and Types of Instructor Interactions in Online Instruction", Journal of Interactive Online Learning, Volume 8, Number 1, Spring 2009.

[20] M. Mazzolini, S. Maddison, "When to jump in: The role of the instructor in online discussion forums", Computers and Education, Vol: 49 (2007), 2007, pp: 193-213.

[21] M. Alavi, D. Dufner, "Technology-mediated collaborative learning: A research perspective", In S. R. Hiltz and R. Goldman (Eds.), Learning together online: Research on asynchronous learning networks, Mahwah, NJ: Lawrence Erlbaum, 2005, pp. 191-213.

[22] D.K. LaPointe, C. N. Gunawardena, "Developing, testing and refining of a model to understand the relationship between peer interaction and learning outcomes in computer-mediated conferencing", Distance Education, Vol: 25:1, 2004, pp: 83-106.

[23] T. Capra, "Online Education: Promise and Problems", Journal of Online Learning and Teaching, Vol. 7, No. 2, June 2011, 288-293.

[24] A. L. Strauss, J. M. Corbin, "Basics of qualitative research: grounded theory procedures and techniques", 2nd ed,Sage Publications, Thousand Oaks, CA,USA, 1998.

[25] W. L. Neuman, "Social research methods: Qualitative and quantitative approaches", 6th Ed, 2006.

[26] Strauss, J. M. Corbin, "Basics of qualitative research: grounded theory procedures and techniques", Sage Publications, Newbury Park, CA, USA, 1990.

[27] B. G. Glaser, A. L. Strauss, "The discovery of grounded theory". Aldine, New York, 1967.

[28] Y. Levy, "Comparing dropouts and persistence in elearning courses. Computer and Education", Vol: 48, 2007, pp: 185-204.

[29] D. Zielinski, "The lie of online learning", Training, 37(2), 2000, pp: 38-40.

[30] D. Laurillard, "Rethinking University Teaching: A Conversational Framework for the Effective Use of Learning Technologies", 2nd ed., London: Routledge, 2002.

[31] C. Klisc,, T. McGill, V. Hobbs, "The effect of assessment on the outcomes of asynchronous online discussion as perceived by instructors", Australasian Journal of Educational Technology, Vol: 25(5),2009, pp: 666-682.

[32] D. Nandi, M.Hamilton, J. Harland, G.Warburton, "How Active are Students in Online Discussion Forums?" Australasian Computing Education Conference (ACE 2011), Perth, Australia. CRPIT, 114. John Hamer and Michael de Raadt Eds., ACS., 2011, 125-134.

[33] P. Gerbic, "To post or not to post: Undergraduate student perceptions about participating in online discussions, In Who's learning? Whose technology?" Proceedings ascilite, Sydney 2006. http://www.ascilite.org.au/conferences/sydney06/proceedi ng/pdf_papers/p124.pdf.

[34] S. Vonderwell, X. Liang, K. Alderman, "Asynchronous discussions and assessment in online learning", Journal of Research on Technology in Education. Vol: 39(3), 2007, pp: 309-328.

[35] Y. Gulatee, B. Combes, "Identifying the Challenges to Teaching Computer Topics Online", International EDU-
COM Conference: Engagement and Empowerment, Khon Kaen University, Nong Khai, Thailand, 22 November 24 November, 2006.

\section{Authors Profiles}

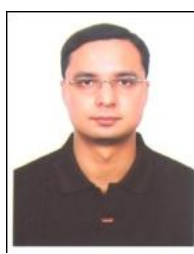

Dip Nandi has completed his $\mathrm{PhD}$ in Computer Science from RMIT University, Melbourne, Australia. His research interests include E-Learning, Software Engineering and Information Systems. Email: dip.nandi@aiub.edu

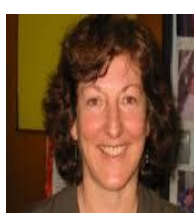

Margaret Hamilton is an Associate Professor in the School of Computer Science and Information Technology at RMIT University, Melbourne, Australia. Her research interests include E-Learning, Data Mining and Web Technologies.

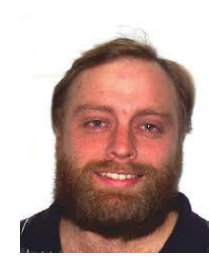

James Harland is an Associate Professor in the School of Computer Science and Information Technology at RMIT University, Melbourne, Australia. His research interests include E-Learning, Computing Theories and Logic Programming.

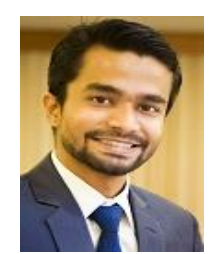

Sharfuddin Mahmood has completed his B.Sc and M.Sc degree in Computer Science from American International UniversityBangladesh. His major was Information and Database Technologies. Currently his is focusing on Data Mining technologies and algorithms. His area of research is Data mining and knowledge discovery and intelligent systems. 